\title{
Evaluation and Screening of Promising Drought Tolerant Chickpea (Cicerarietinum L.) Genotypes Based on Physiological and Biochemical Attributes Under Drought Conditions
}

\author{
Muhammad Jan ${ }^{1 *}$, Tanveer ul $\mathrm{Haq}^{2}$, Hina Sattar ${ }^{3}$ Madiha Butt ${ }^{4}$, Abdul Khaliq ${ }^{5}$, Muhammad Arif ${ }^{6}$ and \\ Abdul Rauf ${ }^{7}$
}

${ }^{1}$ Department of Soil and Environmental Science, Ghazi University, Dera Ghazi Khan, 32200, Pakistan; ${ }^{2}$ Department of Soil and Environmental Sciences, Muhammad Nawaz Sharif University of Agriculture, Multan; ${ }^{3}$ Institute of Soil and Environmental Sciences, University of Agriculture, Faisalabad 38040, Pakistan; ${ }^{4}$ College of Agriculture Bahauddin Zakariya University Bahadur Sub-Campus, Layyah, Pakistan; ${ }^{5}$ Soil \& Water Testing Laboratory Rajan Pur; ${ }^{6}$ Soil and Water Testing Laboratory, Layyah, Pakistan; ${ }^{7}$ Agriculture Officer (Field), Dera Ghazi Khan, Pakistan.

\begin{abstract}
Extreme climatic conditions like heat waves, dry spell, sustained drought and precipitation adversely reducing the crop productivity and these are considered as an alarming issue for the crop production in rainfed areas. Chick pea is deemed to be regarded as a drought sensitive crop. The low water and fertilizer demand and its ability to grow on marginal land is an excellent choice for the farming community. The field trial was conducted with the aspect to screen out the drought-tolerant variety of chick pea keeping in view the physiological and biochemical attributes under drought conditions. Drought stress adversely reduced the vegetative growth in term of primary branches, secondary branches and pod yield. Based on biochemical, morphological and physiological parameters a significant difference was observed among the genotypes. Out of twenty-five genotypes, three chick pea genotypes i-e chick pea genotypes GGP1260, GGP1426 and PB01 shown the best drought tolerance efficiency $(83.78,84.21$ and 81.57\%), harvest index $(83.23,84.06$, and $81.14 \%)$ and minimum reduction in pod yield (16.21, 15.78 and 18.42\%) under rainfed controlled conditions. Under rainfed condition the activity of all enzymes increased among all genotypes. The chick pea genotypes, GGP-1260, PGP-1426 and PB-1 were observed as drought-tolerant ones on the basis of biochemical, morphological and physiological parameters and these can be recommended for rain-fed areas crop selection.

Received | May 29,2020; Accepted | August 07, 2020; Published | August 22, 2020

*Correspondence | Muhammad Jan, Department of Soil and Environmental Science, Ghazi University, Dera Ghazi Khan, 32200, Pakistan; Email:mjanleghari@gmail.com

Citation | Jan, M., T. Haq, H. Sattar, M. Butt, A. Khaliq, M. Arif and A. Rauf. 2020. Evaluation and screening of promising drought tolerant chickpea (Cicer arietinum L.) genotypes based on physiological and biochemical attributes under drought conditions. Pakistan Journal of Agricultural Research, 33(3): 662-672.

DOI | http://dx.doi.org/10.17582/journal.pjar/2020/33.3.662.672

Keywords | Chickpea, Drought tolerance, Water deficit, Yield stability
\end{abstract}

\section{Introduction}

$\mathrm{D}$ rought effects are commonly related to the agriculture and water resource sectors. They may cause substantial economic losses in the agriculture sector of developed countries through reductions in crop yield or total failure of crops (Sweet et al., 2017; Tian et al., 2018). Under certain circumstances they can also cause human migration and famine in developing countries (Gray and Mueller, 2012; 
Grolle, 2015). Hydrological droughts may also cause significant effects to irrigated agricultural systems (Maestro et al., 2016; Vidal-Macua et al., 2018) and problems for urban water supply, industrial needs, reductions of hydropower production, etc. (Balling and Gober, 2007; Jerez et al., 2013; Vicente-Serrano et al., 2020). At the world level, about 35\% of world land having climate arid and semi-arid. In the world, the farmers have adopted low yield set of varieties for the chick pea crop sowing in rain-fed areas. The adaptation of such type of genotypes cultivation restricts the use of optimal inputs (Jackson et al., 2007). The concept of promising drought tolerance of chick pea genotypes becoming a new task for researchers in Pakistan because the current scenario of water shortage, change in climate change due to global warming as well as conversion of irrigated land into colonies adoption (Fahad et al., 2017; Eckstein et al., 2019; Jamro et al., 2020).

In Pakistan, the period of a long drought and sudden rain are the main constraints in yield reduction of chick pea crop because the climate of Pakistan mostly existing in the dry region where the water shortage is the main problem. The climate change effecting the whole world now the scenario is that the Pakistan ranked the toppest $10^{\text {th }}$ of the severely affected countries (Aziz et al., 2017; Fahad et al., 2017). In Pakistan, during rabi season after the wheat chick pea is the second crop which cultivated in Pakistan. The breeding and selection of those genotypes which can grow under drought are considered an effective method to minimize the repercussion of drought exposure (Eckstein et al., 2019; Jamro et al., 2020).

Among the leguminous crops of the world, Chick pea is the $3^{\text {rd }}$ leguminous grain after the dry beans and peas. In Asia, the cultivation and production of the chick pea contribute about $90 \%$. It is also grown in the areas of West Asian and North African (WANA) Region and eastern Africa, the Mediterranean Region and North and Central America (Ali and Kumar, 2001). In Pakistan, Chick pea is considered as second rabi crop after the wheat (GOP, 2015). In Pakistan, lack of marginal land adaptation trend and recent techniques and suitable crop varieties selection are the main constraints for the formers (Vural and Karasu, 2007).

At the global level, among the leguminous crops Chick pea is the $2^{\text {nd }}$ most cultivated crop which is mostly adopted by the arid and semi-arid regions farmers especially Pakistan (Maqbool et al., 2017; Varshney et al., 2014). It is mostly grown under rainfed conditions. Availability of water in rainfed regions is only possible through moisture conserving in sub-tropical areas and during heavy rainfall showers of summer. In these conditions rainfed chickpea plantations encounters the serious yield losses due to terminal drought stress (Turner et al. 2001; Shah et al. 2020). The project was held with the objectives to evaluate the performance of chick pea (Cicera rietinum L.) germplasm under drought and in addition to identify the suitable yielding germplasm under drought condition.

\section{Materials and Methods}

\section{Experimental layout and location}

The planned field trial conducted at Air Port campus in the Research area of Ghazi University, D.G. Khan. There were 25 genotypes which were collected from different research stations (Arid Zone Research Institute, Bhakkar, Ayub Agriculture Research Institute Faisal abad and Nuclear Institute of Agriculture and Bio technology Faisalabad, Pakistan). Three rows of each genotype were sown with 10 seeds per row. Plant - plant distance $30 \mathrm{~cm}$ and row - row distance $45 \mathrm{~cm}$ were maintained. Two main plots were prepared one for irrigated (well-watered) conditions and second, was nominated for rainfed (drought) condition. The design used was RCBD with factorial arrangements and three replications were used. Soil samples were taken from $15-30 \mathrm{~cm}$ and analyzed for the study of Physico-chemical analysis (Table 1).

\section{Table 1: Physico-chemical analysis of soil samples.}

$\begin{array}{lll}\text { Sr. } & \text { Physico-chemical characteristics } & \text { Readings } \\ 1 & \mathrm{ECe}\left(\mathrm{dS} \mathrm{m}^{-1}\right) & 2.05 \\ 2 & \mathrm{pH} & 7.80 \\ 3 & \text { Bulk density }\left(\mathrm{Mg} \mathrm{m}^{-3}\right) & 1.57 \\ 4 & \mathrm{CEC}\left({\left.\mathrm{C} \mathrm{mol} \mathrm{cg}^{-1}\right)}^{-1.12}\right. \\ 5 & \mathrm{SAR} & 8.14 \\ 6 & \text { Texture } & \text { Sandy loam }\end{array}$

\section{Measurements and calculations}

Fresh biomass of chick pea plants was recorded by using an electric balance and calculated means of each treatment. The pods of both unfertile and fertile were recorded for collection of total number of pods per plant. The branches both secondary and primary from each individual plant were recorded and summed up as number of branches per plant. 
Table 2: Effect of terminal drought on pods per plant and fresh biomass per plant $(g)$ under rain fed and irrigated conditions.

\section{Genotypes}

$\begin{array}{lll} & \text { Rain fed conditions (Io) } & \text { Irrigated } \\ \text { PGP-1479 } & 51 \pm 3.87 & 62 \pm 3.55 \\ \text { PGP-1426 } & 73 \pm 4.80 & 80 \pm 3.70 \\ \text { BIC-2006 } & 60 \pm 4.51 & 77 \pm 3.57 \\ \text { OSA-0285 } & 62 \pm 2.78 & 80 \pm 3.45 \\ \text { OSA-005 } & 42 \pm 2.70 & 48 \pm 2.37 \\ \text { Thal-2006 } & 42 \pm 2.18 & 55 \pm 2.45 \\ \text { GGP-1406 } & 58 \pm 3.17 & 73 \pm 2.60 \\ \text { GGP-1458 } & 58 \pm 3.22 & 70 \pm 2.34 \\ \text { NLS-0613 } & 48 \pm 2.27 & 62 \pm 2.87 \\ \text { GGP-1499 } & 51 \pm 2.90 & 66 \pm 2.50 \\ \text { GGP-1484 } & 46 \pm 2.67 & 58 \pm 2.47 \\ \text { GGP-1439 } & 48 \pm 1.79 & 57 \pm 2.40 \\ \text { 93A138 } & 57 \pm 2.27 & 68 \pm 2.51 \\ \text { GGP-1419 } & 29 \pm 2.10 & 40 \pm 1.27 \\ \text { PB-2008 } & 58 \pm 3.97 & 79 \pm 2.85 \\ \text { 06A045 } & 42 \pm 1.68 & 57 \pm 2.34 \\ \text { GGP-1415 } & 54 \pm 1.74 & 75 \pm 2.80 \\ \text { GGP-1260 } & 59 \pm 1.64 & 73 \pm 2.77 \\ \text { 06A09 } & 43 \pm 1.53 & 60 \pm 1.23 \\ \text { GGP-1483 } & 59 \pm 1.61 & 80 \pm 2.80 \\ \text { PB-1 } & 56 \pm 3.78 & 68 \pm 1.34 \\ \text { K-70008 } & 60 \pm 2.87 & 75 \pm 2.77 \\ \text { PB-2000 } & 57 \pm 2.56 & 73 \pm 2.69 \\ \text { Punjab-2008 } & 70 \pm 3.42 & 84 \pm 1.82 \\ \text { Brittle-98 } & 54 \pm 3.52 & 68 \pm 1.32 \\ \text { Grand Mean } & 53.48 & 67.52\end{array}$

Fresh biomass per plant (g)

Rain fed conditions (Io) Irrigated conditions (I1)

$21.90 \pm 1.89$

$39.54 \pm 2.27$

$45.3+2.90$

$47.1 \pm 3.17$

$20.23 \pm 1.08$

$43.05 \pm 3.03$

$17.6+1.65$

$36.18 \pm 2.90$

$22.18 \pm 1.88$

$45.56 \pm 2.94$

$35.1 \pm 2.28$

$71.2 \pm 3.40$

$35.46+2.97$

$73.15+3.87$

$30.13 \pm 3.03$

$62.23 \pm 2.74$

$27.3 \pm 1.84$

$55.12 \pm 2.57$

$15.66 \pm 1.18$

$31.5 \pm 2.17$

$9.96 \pm 0.87$

$22.45+1.87$

$14.5 \pm 0.87$

$30.35 \pm 1.95$

$10.05 \pm 1.07$

$21.43 \pm 1.80$

$9.87 \pm 0.80$

$20.48+1.84$

$16.54 \pm 1.28$

$28.45 \pm 1.98$

$18.22 \pm 1.12$

$37.34 \pm 2.13$

$15.56 \pm 1.13$

$32.25 \pm 2.80$

$35.44 \pm 2.80$

$42.46 \pm 2.90$

$20.25 \pm 1.88$

$43.12 \pm 2.85$

$25.1 \pm 1.90$

$53.42 \pm 3.18$

$44.66 \pm 2.87$

$55.24 \pm 3.25$

$27.36 \pm 1.97$

$56.67 \pm 3.28$

$26.05 \pm 2.14$

$54.23 \pm 3.20$

$33.5+2.30$

$49.24+2.98$

$34.7 \pm 2.80$

$49.45 \pm 2.95$

24.27

44.28
Data were collected before and after harvest, was carried out and data recorded on all aspects of the test entries including days to flowering initiation, branches (primary and secondary), plant height, fresh biomass per plant were measured. The method of Fischer and Maurer (1978) was followed to calculate $\%$ reduction in yield. Drought Tolerance Efficiency (DTE) and Harvest Index (HI) were calculated by Donald and Hamblin (1976) and Fischer and Wood (1981) given formulas.

$$
\begin{aligned}
& \text { DroughtTolerance Efficiency }(\%)=\frac{\text { Yield in rainfed }}{\text { Yield in non rainfed }} \times 100 \\
& \text { Harvest Index }(\mathrm{HI})=\frac{\text { Grain Yield }}{\text { Biological Yield }} \times 100 \\
& \text { Percent Reduction }=\frac{\text { Yield in non rainfed - Yield in rainfed }}{\text { Yield in non rainfed }} \times 100
\end{aligned}
$$

To evaluate the activity of different antioxidant enzymes, half a gram of fresh sample of the leaf was ground a cold ice bath in a solution of in cold $\mathrm{PO}_{4}$ buffer solution Homogeneous mixture centrifuged at $15000 \mathrm{rpm}$ at the temperature of $4{ }^{\circ} \mathrm{C}$ for 20 minutes.

The activity of super oxidismutase was estimated by the nitroblue tetra zolium (NB T) photo reduction by the Giannopolitis and Ries (1977) method. The absorbance wave length was $560 \mathrm{~nm}$ adjusted on UV-VIS spectro photometer. Each enzyme activity and protein contents were recorded by the suggested method of Bonjoch and Tamayo (2001). The activities of POD and CAT were calculated through the method of Chance and Maehly (1955) which were estimated as a absorbance change of 0.01units in a duration of one minute at a wavelength of $240 \mathrm{~nm}$ and $470 \mathrm{~nm}$. 
Table 3: Effect of terminal drought on primary branches and secondary branches under rain fed (Io) and irrigated (I1) condition.

\section{Genotypes}

PGP-1479

PGP-1426

BIC-2006

OSA-0285

OSA-005

Thal-2006

GGP-1406

GGP-1458

NLS-0613

GGP-1499

GGP-1484

GGP-1439

93A138

GGP-1419

PB-2008

06A045

GGP-1415

GGP-1260

06A09

GGP-1483

PB-1

K-70008

PB-2000

Punjab-2008

Brittle-98

Grand Mean

\section{Primary branches}

\section{Rain fed conditions (Io) Irrigated conditions (I1)}

$2.33 \pm 0.37$

$4.07 \pm 1.27$

$3.24 \pm 0.70$

$3.20 \pm 1.75$

$3.90 \pm 1.17$

$3.42 \pm 1.53$

$3.56 \pm 1.17$

$3.87 \pm 1.32$

$3.95 \pm 1.30$

$2.90 \pm 0.61$

$3.76 \pm 1.23$

$3.70 \pm 1.15$

$3.89 \pm 1.22$

$2.98 \pm 0.99$

$3.04 \pm 1.07$

$3.10 \pm 1.43$

$3.78 \pm 1.54$

$3.11 \pm 1.05$

$3.90 \pm 1.08$

$3.98 \pm 1.12$

$3.42 \pm 1.01$

$4.50 \pm 1.24$

$4.33 \pm 1.16$

$4.26 \pm 1.18$

$4.48 \pm 1.20$

3.63

\section{Secondary branches}

$\begin{array}{ll}\text { Rain fed conditions }(I o) & \text { Irrigated conditions (I1) } \\ 08.10 \pm 1.87 & 10.12 \pm 1.03 \\ 11.60 \pm 2.11 & 12.10 \pm 1.27 \\ 7.30 \pm 1.65 & 9.38 \pm 0.87 \\ 7.50 \pm 1.70 & 9.57 \pm 0.93 \\ 7.80 \pm 1.67 & 9.90 \pm 0.84 \\ 8.15 \pm 1.80 & 10.20 \pm 1.02 \\ 8.25 \pm 1.84 & 10.30 \pm 1.03 \\ 9.27 \pm 1.89 & 11.30 \pm 1.10 \\ 9.40 \pm 1.91 & 11.34 \pm 1.08 \\ 9.50 \pm 1.92 & 11.56 \pm 1.12 \\ 9.75 \pm 1.93 & 11.80 \pm 1.01 \\ 9.65 \pm 1.80 & 11.67 \pm 1.14 \\ 9.35 \pm 1.66 & 11.41 \pm 1.11 \\ 8.87 \pm 1.87 & 10.90 \pm 0.97 \\ 8.90 \pm 1.96 & 10.84 \pm 1.07 \\ 9.20 \pm 1.45 & 11.23 \pm 1.10 \\ 9.40 \pm 1.50 & 11.34 \pm 1.11 \\ 10.52 \pm 2.09 & 10.65 \pm 1.02 \\ 9.20 \pm 1.47 & 11.23 \pm 1.00 \\ 9.70 \pm 1.53 & 11.78 \pm 1.13 \\ 11.20 \pm 2.10 & 12.15 \pm 1.17 \\ 10.15 \pm 2.07 & 12.2 \pm 1.02 \\ 10.20 \pm 2.01 & 12.15 \pm 1.18 \\ 9.90 \pm 1.18 & 11.89 \pm 1.12 \\ 10.20 \pm 2.07 & 12.17 \pm 1.17 \\ 9.32 & 11.17 \\ & \end{array}$

\section{Statistical analysis}

The differences among the treatments means was measured through statistical analysis in RCBD 2 factorial arrangement (Steel et al., 1997) by using Statistics 8.1 software.

\section{Results and Discussion}

\section{Fresh biomass per plant (g) and pods per plant}

The genotypes PGP-1426, GGP-1260 and PB-01 revealed highest fresh biomass per plant in rainfed conditions $(39.54 \pm 2.27,35.44 \pm 2.80$ and $44.66 \pm 2.87)$ and irrigated conditions $(47.1 \pm 3.17,42.46 \pm 2.90$ and $55.24 \pm 3.25)$. The genotype GGP-1406 exhibited maximum fresh biomass per plant in irrigated conditions $73.15 \pm 3.87$ ) while genotype PB-1 (44.66 \pm 2.87$)$ exhibited maximum fresh biomass per plant under rainfed conditions (Table 2). Maximum pods per plant (73.0, 59.00 and 56.00) in PGP-1426, GGP-1260 and PB-01 were recorded under water rainfed condition and while in case of non-rainfed conditions similar trend also observed in case of pods per plant (80.00, 73.00 and 68.00) (Table 2).

\section{Primary branches and secondary branches}

The vegetative growth is one of the important growth stages which actually govern all phenotypic expression and grain yield. The height of plants, primary branches and secondary branches are main attributes for estimation of vegetative growth and al has a specific function. Chick pea genotypes like PGP-1426, GGP-1260 and PB-01 showed the least reduction in case of primary, secondary branches and plant height compared to remaining ones genotypes under both 
irrigated and rainfed conditions (Table 2). Primary branches $(3.93 \pm 0.57,3.11 \pm 1.02$ and $3.53 \pm 0.97)$ in rain-fed were maintained by PGP-1426, GGP-1260 and $\mathrm{PB}-01$ respectively while $(4.07 \pm 1.27,3.11 \pm 1.05$ and $3.42 \pm 1.01)$ under irrigated condition. In case of irrigated condition Brittle-98 showed maximum primary branches $(4.48 \pm 1.20)$ and Punjab-2008 gave highest primary branches $(4.13 \pm 1.07)$ under rainfed condition. Maximum number of secondary branches under rainfed condition $(11.60 \pm 2.11,10.52 \pm 2.09$ and $11.20 \pm 2.10)$ were recorded by PGP-1426, GGP-1260 and PB-01 respectively while secondary branches $(12.10 \pm 1.27,10.65 \pm 1.02$ and $12.15 \pm$ 1.17) were under irrigated conditions. The highest secondary branches under irrigated conditions were recorded by Brittle-98 chick pea genotype (Table 3).
Effect of antioxidant enzymes activity

The production of ROS under stress condition can be controlled by different antioxidant enzyme which can be detoxified by three enzymes i-e. SOD, POD and CAT. The enzymatic activities were determined to estimate the pant survival under stress condition.

\section{Superoxide dismutase (SOD)}

To select drought-tolerant genotypes, there are several advanced molecular techniques; one of them is the determination of SOD. The highest activity of SOD (Unit $195 \pm 1.25 \mathrm{mg}^{-1}$ protein) was observed in GGP1406 under rain-fed condition and the minimum activity of SOD was observed in OSA-005 under irrigated conditions (Unit $100 \pm 1.09 \mathrm{mg}^{-1}$ protein) (Table 4).

Table 4: Effect of terminal drought on SOD, POD and CAT activity activities in chick pea under rain fed and irrigated conditions.

\begin{tabular}{|c|c|c|c|c|c|c|}
\hline \multirow[t]{2}{*}{ Genotypes } & \multicolumn{2}{|c|}{ SOD activity ( $\mathrm{U} \mathrm{mg}^{-1}$ protein) } & \multicolumn{2}{|c|}{ POD activity $\left(\mathrm{U} \mathrm{mg}^{-1}\right.$ protein $)$} & \multicolumn{2}{|c|}{ CAT activity ( $\mathrm{U} \mathrm{mg}^{-1}$ protein) } \\
\hline & $\begin{array}{l}\text { Rain fed condi- } \\
\text { tions (Io) }\end{array}$ & $\begin{array}{l}\text { Irrigated condi- } \\
\text { tions (I1) }\end{array}$ & $\begin{array}{l}\text { Rain fed condi- } \\
\text { tions (Io) }\end{array}$ & $\begin{array}{l}\text { Irrigated } \\
\text { onditions (I1) }\end{array}$ & $\begin{array}{l}\text { Rain fed } \\
\text { onditions (Io) }\end{array}$ & $\begin{array}{l}\text { Irrigated } \\
\text { onditions (I1) }\end{array}$ \\
\hline PGP-1479 & $150 \pm 4.50$ & $145 \pm 1.23$ & $1.41 \pm 0.78$ & $1.22 \pm 0.68$ & $26.49 \pm 1.18$ & $19.38 \pm 0.98$ \\
\hline PGP-1426 & $178 \pm 3.68$ & $148 \pm 2.34$ & $2.03 \pm 0.90$ & $1.57 \pm 0.38$ & $37.53 \pm 1.43$ & $29.55 \pm 0.77$ \\
\hline BIC-2006 & $150 \pm 2.68$ & $123 \pm 1.45$ & $1.63 \pm 0.23$ & $1.37 \pm 0.21$ & $25.63 \pm 1.30$ & $15.74 \pm 0.58$ \\
\hline OSA-0285 & $150 \pm 1.60$ & $105 \pm 1.34$ & $1.68 \pm 0.34$ & $1.34 \pm 0.17$ & $30.33 \pm 1.18$ & $20.37 \pm 0.90$ \\
\hline OSA-005 & $154 \pm 1.58$ & $100 \pm 1.09$ & $1.43 \pm 0.29$ & $1.23 \pm 0.05$ & $39.45 \pm 1.18$ & $34.74 \pm 0.88$ \\
\hline Thal-2006 & $162 \pm 1.08$ & $112 \pm 1.12$ & $1.37 \pm 0.45$ & $1.26 \pm 0.18$ & $38.11 \pm 1.10$ & $32.29 \pm 0.56$ \\
\hline GGP-1406 & $195 \pm 1.25$ & $175 \pm 1.21$ & $1.49 \pm 0.59$ & $1.33 \pm 0.28$ & $39.33 \pm 1.08$ & $29.45 \pm 0.68$ \\
\hline GGP-1458 & $177 \pm 2.38$ & $127 \pm 1.38$ & $1.46 \pm 0.73$ & $1.39 \pm 0.20$ & $34.07 \pm 1.70$ & $30.44 \pm 0.75$ \\
\hline NLS-0613 & $145 \pm 2.48$ & $115 \pm 1.54$ & $1.85 \pm 0.84$ & $1.73 \pm 0.03$ & $33.96 \pm 2.78$ & $23.91 \pm 0.70$ \\
\hline GGP-1499 & $153 \pm 1.88$ & $117 \pm 1.21$ & $1.73 \pm 0.88$ & $1.68 \pm 0.04$ & $36.29 \pm 2.80$ & $26.28 \pm 0.84$ \\
\hline GGP-1484 & $133 \pm 1.34$ & $120 \pm 1.68$ & $1.92 \pm 0.08$ & $1.77 \pm 0.02$ & $30.78 \pm 2.71$ & $20.52 \pm 0.78$ \\
\hline GGP-1439 & $117 \pm 1.67$ & $115 \pm 1.82$ & $1.98 \pm 0.38$ & $1.94 \pm 0.21$ & $29.60 \pm 1.70$ & $19.27 \pm 0.56$ \\
\hline 93A138 & $138 \pm 1.78$ & $104 \pm 1.90$ & $1.41 \pm 0.54$ & $1.22 \pm 0.78$ & $33.78 \pm 1.54$ & $23.45 \pm 0.66$ \\
\hline GGP-1419 & $155 \pm 1.50$ & $115 \pm 1.93$ & $1.43 \pm 0.50$ & $1.27 \pm 0.21$ & $36.75 \pm 1.50$ & $26.78 \pm 0.67$ \\
\hline PB-2008 & $174 \pm 1.56$ & $163 \pm 1.60$ & $1.63 \pm 0.68$ & $1.37 \pm 0.18$ & $30.25 \pm 1.78$ & $27.25 \pm 0.34$ \\
\hline 06А045 & $133 \pm 1.45$ & $113 \pm 1.45$ & $1.68 \pm 0.18$ & $1.34 \pm 0.13$ & $33.75 \pm 2.23$ & $31.50 \pm 0.45$ \\
\hline GGP-1415 & $155 \pm 1.76$ & $145 \pm 1.23$ & $1.43 \pm 0.08$ & $1.23 \pm 0.04$ & $37.00 \pm 2.05$ & $29.21 \pm 0.67$ \\
\hline GGP-1260 & $179 \pm 1.77$ & $129 \pm 1.14$ & $2.17 \pm 0.18$ & $1.56 \pm 0.23$ & $41.25 \pm 1.78$ & $31.25 \pm 0.70$ \\
\hline 06A09 & $140 \pm 1.59$ & $133 \pm 1.29$ & $1.49 \pm 0.10$ & $1.33 \pm 0.21$ & $32.75 \pm 2.15$ & $29.25 \pm 0.68$ \\
\hline GGP-1483 & $144 \pm 1.23$ & $107 \pm 1.16$ & $1.46 \pm 0.68$ & $1.39 \pm 0.34$ & $33.27 \pm 2.12$ & $25.43 \pm 0.36$ \\
\hline PB-1 & $190 \pm 2.68$ & $119 \pm 1.10$ & $2.15 \pm 0.23$ & $1.93 \pm 0.78$ & $38.05 \pm 1.78$ & $30.50 \pm 0.30$ \\
\hline K-70008 & $139 \pm 3.38$ & $128 \pm 2.08$ & $1.73 \pm 0.60$ & $1.68 \pm 0.78$ & $30.35 \pm 1.90$ & $29.75 \pm 0.45$ \\
\hline PB-2000 & $120 \pm 1.05$ & $107 \pm 2.00$ & $1.92 \pm 0.20$ & $1.77 \pm 058$ & $32.56 \pm 1.58$ & $28.25 \pm 0.50$ \\
\hline Punjab-2008 & $160 \pm 1.23$ & $127 \pm 1.18$ & $1.98 \pm 0.16$ & $1.94 \pm 0.98$ & $29.50 \pm 1.08$ & $27.75 \pm 0.63$ \\
\hline Brittle-98 & $150 \pm 1.20$ & $141 \pm 1.13$ & $1.44 \pm 0.06$ & $1.46 \pm 0.23$ & $32.32 \pm 0.78$ & $29.13 \pm 0.65$ \\
\hline Grand Mean & 154.08 & 125.32 & 1.676 & 1.49 & 33.84 & 26.84 \\
\hline
\end{tabular}


Peroxidase (POD)

The maximum POD enzyme quantity obtained under drought rainfed condition (Unit 2.17 \pm 0.18 $\mathrm{mg}^{-1}$ protein) by GGP-1260 under rainfed conditions and the lowest POD enzyme activity of the enzyme found in PGP-1479 under irrigated conditions (Unit $1.22 \pm 0.68 \mathrm{mg}^{-1}$ protein) (Table 4).

\section{Catalase (CAT)}

CAT has a role in the decomposition of peroxidase under environmental rainfed condition and plant tolerance to the rain-fed. Under rainfed condition, maximum CAT activity (Unit $41.25 \pm 1.78 \mathrm{mg}^{-1}$ protein) was observed by GGP-1260 and under irrigated condition; BIC-2006 (Unit 15.74_ 0.58 $\mathrm{mg}^{-1}$ protein) had the lowest CAT enzyme activity (Table 4).

\section{Drought tolerance efficiency, harvest index and percent reduction yield}

Among the all genotypes, the best efficiency of drought tolerant was observed in three chick pea genotypes i-e GGP1260 (83.78),_PGP1426 (84.21) andPB-01 and (81.58 $\pm 1.23 \%)$ respectively, good harvest index $(84.07 \pm 3.89,83.24 \pm 2.68$ and $81.15 \pm$ $0.68 \%)$ and minimum reduction in seed yield (15.79+ $1.61,16.22 \pm 0.78$ and $18.42 \pm 1.04 \%)$ in rainfed environment (Table 5).

The fresh biomass of all chick pea genotypes decreased under rainfed condition. The fresh biomass of plant was dependent on genotypic makeup of chick pea genotypes as some genotypes gave more root fresh and dry weight under rainfed conditions rather than other chick pea genotypes. The dry matter production or yield development rate reduced under rain-fed conditions and also under over irrigated conditions. It may be because of the reasons that under rainfed water shortage diminished the rate of photosynthetic tracked by hindering the fertilization hindrance and shedding of the flower. Similar findings were also observed (Waqas et al., 2019; Sharma et al., 2020). In the case of irrigated conditions, less pod number observed due to more vegetative growth as a result of less light penetration and air circulation (Shan and Wang, 2017; Farooq et al., 2018). These discoveries are similar to the findings of Shrafi et al. (2014) as they observed in case of dry matter accumulation and growth rate of crop. It might be because of lacking dissolvable for photosynthetic and metabolic exercises. The production of seed and pod are also dependent on the number of secondary branches in chickpea which was significant. Moucheshi et al. (2011) also reported similar observations under drought conditions. A reduction in seed yield of $26.2 \%$ in chickpea crop was also observed under the conditions of rainfed by other researchers (Anjum et al., 2011; Walter et al., 2013; Tabassum et al., 2017).

Table 5: Effect of terminal drought on drought tolerance efficiency, good harvest index and minimum reduction in seed yield under rain fed condition.

\begin{tabular}{llll} 
Genotypes & $\begin{array}{l}\text { Drought tolerance } \\
\text { efficiency }(\%)\end{array}$ & $\begin{array}{l}\text { Harvest } \\
\text { index }(\%)\end{array}$ & $\begin{array}{l}\text { Reduction in } \\
\text { seed yield (\%) }\end{array}$ \\
PGP-1479 & $74.29 \pm 2.68$ & $59.65 \pm 2.68$ & $25.71 \pm 1.28$ \\
PGP-1426 & $84.21 \pm 1.60$ & $84.07 \pm 3.89$ & $15.79 \pm 1.61$ \\
BIC-2006 & $80.56 \pm 1.38$ & $62.28 \pm 1.80$ & $19.44 \pm 1.12$ \\
OSA-0285 & $82.86 \pm 1.37$ & $65.47 \pm 1.28$ & $17.14 \pm 1.10$ \\
OSA-005 & $78.79 \pm 1.28$ & $61.33 \pm 1.08$ & $21.21 \pm 1.18$ \\
Thal-2006 & $75.00 \pm 3.68$ & $57.27 \pm 2.07$ & $25.00 \pm 0.98$ \\
GGP-1406 & $77.14 \pm 3.70$ & $57.75 \pm 1.28$ & $22.86 \pm 1.04$ \\
GGP-1458 & $80.56 \pm 3.54$ & $60.20 \pm 1.34$ & $19.44 \pm 1.18$ \\
NLS-0613 & $76.47 \pm 2.80$ & $59.81 \pm 1.23$ & $23.53 \pm 1.05$ \\
GGP-1499 & $83.87 \pm 3.39$ & $66.66 \pm 1.10$ & $16.13 \pm 1.09$ \\
GGP-1484 & $72.73 \pm 2.68$ & $61.24 \pm 1.18$ & $27.27 \pm 1.77$ \\
GGP-1439 & $74.29 \pm 1.60$ & $61.97 \pm 1.08$ & $25.71 \pm 1.65$ \\
93A138 & $80.00 \pm 2.00$ & $67.43 \pm 1.68$ & $20.00 \pm 1.54$ \\
GGP-1419 & $78.79 \pm 2.13$ & $67.07 \pm 1.56$ & $21.21 \pm 1.50$ \\
PB-2008 & $77.14 \pm 2.00$ & $68.62 \pm 1.36$ & $22.86 \pm 1.67$ \\
06A045 & $73.33 \pm 1.56$ & $59.73 \pm 1.09$ & $26.67 \pm 1.45$ \\
GGP-1415 & $77.78 \pm 1.57$ & $63.82 \pm 1.63$ & $22.22 \pm 1.40$ \\
GGP-1260 & $83.78 \pm 1.49$ & $83.24 \pm 2.68$ & $16.22 \pm 0.78$ \\
06A09 & $74.29 \pm 1.34$ & $59.20 \pm 1.18$ & $25.71 \pm 1.60$ \\
GGP-1483 & $80.56 \pm 1.60$ & $60.50 \pm 1.78$ & $19.44 \pm 1.06$ \\
PB-1 & $81.58 \pm 1.23$ & $81.15 \pm 0.68$ & $18.42 \pm 1.04$ \\
K-70008 & $81.08 \pm 1.12$ & $61.24 \pm 1.60$ & $18.92 \pm 1.10$ \\
PB-2000 & $83.33 \pm 2.34$ & $62.12 \pm 1.56$ & $16.67 \pm 1.14$ \\
Punjab-2008 & $82.86 \pm 2.68$ & $74.19 \pm 1.77$ & $17.14 \pm 1.03$ \\
Brittle-98 & $81.08 \pm 2.70$ & $74.84 \pm 1.34$ & $18.92 \pm 1.00$ \\
Grand Mean & 79.05 & 65.63 & 20.95 \\
\hline
\end{tabular}

The enhancement of SOD activity in droughttolerant cultivar of chick pea was also reported by some other researchers (Subbarao et al., 2013; Gupta, 2016; Farooq et al., 2018). Besides, Zandalinas et al. (2017) also observed that SOD lead to higher protection against drought conditions. SOD activity scavenge the toxic radicles like superoxide, hydrogen peroxide and then convert them into water and oxygen through the further activity of POD, CAT and APX 
which were tolerant (Patel and Hemantaranjan, 2012; Kadkhodaie et al., 2014; Dalvi et al., 2018). Sensitive genotypes showed less increment was observed superoxidismutase activity under drought conditions which develop as a result of low water potential of the cultivar to remove superoxide. The SOD over expression compensated by the highest scavenging system of hydrogen peroxide like catalase and peroxidase enzyme activities which is a better tool for anti-drought mechanism to compete for stress under conditions of drought (Raheleh et al., 2012; Oberoi et al., 2014).

In the case of chick pea crop, the activity of peroxidase is also observed by (Mafakheri et al., 2011; Kaur et al., 2013; Khadraji et al., 2016). According to their findings, higher concentration of ascorbic acid is minimized by the activity of peroxidase which function as a defensive system for the plant. Similar finding was also observed by Fan et al . (2017) in the cucumber leaves. Peroxidase scavenges hydrogen per oxide which actually produced from peroxide dismutation and catalyzed by superoxidismutase as observed in Phaseolusvulgaris and Phaseolusacutifolius (Turkan et al., 2005; Raheleh et al., 2012; Meena et al., 2014). Increase in peroxidase activity under drought condition has also been reported by (Patel and Hemantaranjan, 2012; Singh et al., 2012; Wu et al., 2014) in chickpea.

Hydrogen peroxide scavenge hydrogen peroxide and form water and oxygen reported. Enhancement was observed in the activity of Catalase in tolerant chickpea genotypes compared to susceptible genotypes (Raheleh et al., 2012). Maximum activity of catalase in tolerant faba bean also reported by Abid et al. (2016), in Green gram, Rambabu et al. ( 2016) and Phaseolus vulgaris L. by Kusvura and Dasgan (2017). In the light of current findings, it is concluded that under rainfed condition the activity of all enzymes increased among the all genotypes GGP-1260, PGP1426 and $\mathrm{PB}-1$ are considered as tolerant ones.

A lesser reduction was observed in morphophysiological attributes and maintenance in yield stability by PGP-1426, GGP-1260 and PB-01 chick pea genotypes in rain-fed as well as irrigated condition. All these attributes result into minimum drought susceptible index and yield reduction. In contrast, maximum drought tolerance efficiency which are in line with the consideration of Ouji et al. (2016) as they reported that very low values of membrane injury index and highest harvest index in irrigated conditions as well as rain-fed condition. Similar observations were also observed by Khoiwal et al. (2017). They also concluded that the tolerant genotype of chick pea maintained highest harvest index, minimum reduction in seed yield and having maximum efficiency and minimum susceptibility index of drought under rainfed condition.

\section{Conclusions and Recommendations}

The higher production of fresh biomass and pod yield among the morphological feature, the highest activity of CAT, POD and SOD among the biochemical attributes and minimum reduction in seed yield, maximum DTE, minimum DSI and highest $\mathrm{HI}$ under rainfed conditions by chick pea genotypes (PGP1426, GGP-1260 and PB-01) as compared to the other genotypes are the best indicator for the drought tolerance efficiency criteria for the mentioned chick pea genotypes. Based on these results, it was concluded that the chick pea genotypes i-e GGP-1260, PGP1426 and $\mathrm{PB}-01$ is the most drought tolerance chick pea genotypes and these can yield well under drought or rainfed condition as that have the capability to grow and generate well. Furthermore, the results from this research depict that adaptation of these screened out drought-tolerant chick pea genotypes improve the economy of farmer community especially the farmer of the rainfed area.

\section{Author's Contribution}

Muhammad Jan conceived the ideas of research and conducted experiment. Tanveer ul Haq helped in management of article. Hina Sattar worked for language improvement of manuscript. Madiha Butt helped in analysis of data. Abdul Khaliq prepared first draft. Muhammad Arif provided technical input. Abdul Rauf helped for manuscript improvement.

\section{Conflict of interest}

The authors have declared no conflict of interest.

\section{References}

Abid, G., M. Muhamdi, D. Mingeot, M. Aouida M, I. Aroua, Y.Muhovski, K. Sassi, F. Souissi, K. Mannai and M. Jebara. 2017. Effect of drought stress on chlorophyll fluorescence, antioxidant 
enzyme activities and gene expression patterns in faba bean (Vicia faba L.). Arch. Agron. Soil Sci. 63: 536-552. https://doi.org/10.1080/0365 0340.2016.1224857

Ali, M. and S. Kumar. 2001. An overview of chickpea research in India. Indian J. Pulses Resour., 14: 81-89.

Anjum, S., X.Y. Xie, L.C. Wang, M.F. Saleem, C. Man and W. Lei. 2011. Morphological, physiological and biochemical responses of lants to drought stress. Afr. J. Agric. Res. 6: 2026-2032.

Aziz, K., K.Y.T. Daniel, Z.A. Muhammad, L. Honghai, A.T. Shahbaz, A. Mir and S. Fahad. 2017. Nitrogen fertility and abiotic stresses management in cotton crop: A review. Environ. Sci. Pollut. Res. 24: 14551-14566. https://doi. org/10.1007/s11356-017-8920-x

Balling R.C. and P. Gober. 2007. Climate variability and residential water use in the city of Phoenix, Arizona. J. Appl. Meteorol. Clim. 46(7): 11301137. https://doi.org/10.1175/JAM2518.1

Bonjoch, N.P. and P.R. Tamayo. 2001. Protein content quantification by Bradford method. In: Handbook of plant ecophysiology techniques. Springer, Dordrecht. pp. 283-295. https://doi.org/10.1007/0-306-48057-3_19

Chance, M. and A.C. Maehly. 1955. Assay of catalases and peroxidases. Methods Enzymol. 2: 764-817. https://doi.org/10.1016/S00766879(55)02300-8

Dalvi, U.S., R.M. Naik and P.K. Lokhande. 2018. Antioxidant defense system in chickpea against drought stress at pre-and post-flowering stages. Ind. J. Plant Physiol. 23(1): 16-23. https://doi.org/10.1007/s40502-017-0322-z

Donald, C. and M. Hamblin. 1976. The biological yield and harvest index of cereals on agronomic and plant breeding criteria. Adv. Agron. 28: 361-405. https://doi.org/10.1016/S00652113(08)60559-3

Eckstein, D., V. Künzel, L. Schäfer and M. Winges. 2019. Global climate risk index 2020. Bonn Ger., 2019: 9.

Fahad, S., A.A. Bajwa, U. Nazir, S.A. Anjum, A. Farooq, A. Zohaib, S. Sadia, W. Nasim, S. Adkins, S. Saud, M.Z. Ihsan, H. Alharby, C.Wu, D. Wang and J. Huang. 2017. Crop production under drought and heat stress: Plant responses and management options. Front. Plant Sci., 8: 1147. https://doi.org/10.3389/fpls.2017.01147
Fan,H.,L.Ding,Y.Xu and C.Du.2017.Antioxidant system and photosynthetic characteristics responses to short-term PEG-induced drought rain stress in cucumber seedling leaves. Russ. J. Plant Physiol., 64: 162-173. https://doi. org/10.1134/S1021443717020042

Farooq, M., U. Aman, D. Lee and S.S. Alghamdi. 2018. Terminal drought-priming improves the drought tolerance in desi and kabuli chickpea. Int. J. Agric. Biol. 20(5): 1129-1136.

Fischer, R.A. and R. Maurer. 1978. Drought resistance in spring wheat cultivars. I. Grain yield responses in spring wheat. Aust. J. Agric. Sci., 29: 892-912. https://doi.org/10.1071/ AR9780897

Fischer, K.S. and G. Wood. 1981. Breeding and selection for drought tolerance in tropical maize. Proc. Symp. Principles Methods Crop Imprt. Drought Resist. Emphasis Rice, IRRI, Philippines.

Giannopolitis, C.N. and S.K. Ries. 1977. Superoxide dismutases. I. Occurrence in higher plants. Plant Physiol. 59: 309-314. https://doi. org/10.1104/pp.59.2.309

GOP (Govt. of Pakistan). 2015. Pakistan bureau of statistics. Natural Resources Division, Pakistan Agricultural Research Council, Islamabad.

Grolle, J., 2015. Historical case studies of famines and migrations in the West African Sahel and their possible relevance now and in the future. Popul. Environ., 37(2): 181-206. https://doi. org/10.1007/s11111-015-0237-4

Gray, C. and V. Mueller. 2012. Drought and Population Mobility in Rural Ethiopia. World Dev., 40(1): 134-145.https://doi.org/10.1016/j. worlddev.2011.05.023

Gupta, K., 2016. Ameliorative effect of sodium nitroprusside and trichoderma on morphophysiological, biochemical and antioxidant enzyme activity in chickpea (Cicer arietinum L.) genotypes under drought stress. Institute of Agricultural Sciences, Banaras Hindu University, Varanasi.

Jackson, L.E., U. Pascual and T. Hodkin. 2007. Utilizing and conserving agro biodiversity in agricultural landscapes. Agro Ecol. Syst. Environ. 121: 196-210. https://doi. org/10.1016/j.agee.2006.12.017

Jamro, S., F.N. Channa, G.H. Dars, K. Ansari and N.Y. Krakauer. 2020. Exploring the Evolution of Drought Characteristics in Balochistan, 
Pakistan. Appl. Sci. 10(3): 913. https://doi. org/10.3390/app10030913

Jerez, S. and R.M. Trigo. 2013. Time-scale and extent at which large-scale circulation modes determine the wind and solar potential in the Iberian Peninsula. Environ. Res. Lett. 8(4): 044035. https://doi.org/10.1088/17489326/8/4/044035

Kadkhodaie, A., M. Zahedi, J. Razmjoo and M. Pessarakli. 2014. Changesin some antioxidativeenzymes and physiologicalindices among sesamegenotypes (Sesamum indicumL.) in response to soil water deficits under field conditions. Acta Physiol. Planta. 36: 641-650. https://doi.org/10.1007/s11738-013-1442-3

Kaur, K., N. Kaur, A. Gupta and I. Singh. 2013. Exploration of the antioxidative defense system to characterize chickpea genotypes showing differential response towards water deficit conditions. Plant Growth Regul. 70: 49-60. https://doi.org/10.1007/s10725-012-9777-0

Khadraji, A., M. Mouradi, C. Houasli, A. Qaddoury and C. Ghoulam. 2016. Growth and antioxidant responses during early growth of winter and spring chickpea (Cicer arietinum) under water deficit as affected by osmopriming. Seed Sci. Technol., 45(1): 198-211. https://doi. org/10.15258/sst.2017.45.1.16

Khoiwal, S., M. Jain, H. Jatav and S.K. Dhawal. 2017. Effect of moisture rainfed conditions on different varieties of chickpea and its growth and yield effect. Environ. Ecol. 35: 1832-1839.

Kusvuran, S., and H.Y. Dasgan. 2017. Effects of drought rainfed on physiological and biochemical changes in Phaseolus vulgaris $\mathrm{L}$. Legume Res. Int. J. 40: 55-62. https://doi. org/10.18805/lr.v0i0.7025

Maestro, T., M. Bielza and A. Garrido. 2016. Hydrological drought index insurance for irrigation districts in Spain. Spanish J. Agric. Res. 14(3): e0105. https://doi.org/10.5424/ sjar/2016143-8981

Mafakheri, A., A. Siosemardah, B. Bahramnejad, P. Struik and Y. Sohrabi. 2011. Effect of drought rainfed and subsequent recovery on protein, carbohydrate contents, catalase and peroxidase activities in three chickpea (Cicer arietinum) cultivars. Aust. J. Crop Sci. 5: 1250- 1255.

Maqbool, M.A., M. Aslam and H. Ali. 2017. Breeding for improved drought tolerance in chickpea (Cicer arietinum L.). Plant Breed. 136:
300-318. https://doi.org/10.1111/pbr.12477

Meena,N.,K.Ali,P.S.Dehmukh and A.Tyagi.2014. Effect of heat stress on physio-biochemical characteristics of chickpea (Cicer arietinum) genotypes. Ind. J. Agric. Sci., 84: 401-406.

Moucheshi, A., B. Heidari and A. Dadkhodie. 2011. Genetic variation and agronomic evaluation of chickpea cultivars for grain yield and its components under irrigated and rainfed growing conditions. Iran Agric. Res. 29: 39-50.

Oberoi, H.K., A.K. Gupta, S. Kaur and I. Singh. 2014. Stage specific upregulation of antioxidant defence system in leaves for regulating drought tolerance in chickpea. J. Appl. Nat. Sci. 6: 326337. https://doi.org/10.31018/jans.v6i2.423

Ouji, A., S. Elbok, M. Mouelhi, B. Younes, and M. Kharrat. 2016. Yield and yield components of chickpea (Cicer arietinum L.) as influenced by supplemental irrigation under semi-arid region of Tunisia. World J. Agric. Res. 4: 153-157.

Patel, P.K. and A. Hemantaranjan. 2012. Salicylic acid induced alteration in dry matter partitioning, anti oxidant defencesystem and yield in chickpea(Cicer arietinum L.) under drought stress. Asian J. Crop Sci. 4: 86-102. https://doi.org/10.3923/ajcs.2012.86.102

Raheleh, R., K.N. Ramzanali, G. Ali, B. Abdolreza, N. Farzaneh and R. Masoud. 2012. Use of biochemicalindices and anti oxidantenzymes as a screeningtechnique for drought tolerance in Chickpeagenotypes (Cicerarietinum L.). Afr. J. Agric. Res. 7: 5372-5380.

Rambabu, B., V. Padm, R. Thatikunta and N. Sunil. 2016. Effect of drought rainfed on chlorophyll content and anti-oxidant enzymes of green gram genotypes (Vigna radiata L.). Nat. Environ. Pollut. Technol. 15: 1205.

Shah, T.M., M. Imran, B.M. Atta, M.Y. Ashraf, A. Hameed, I. Waqar and M.A. Maqbool. 2020. Selectionand screening ofdrought toleranthigh yieldingchickpea genotypes based on physio -bio chemical indicesand multi - environmental yield trials. BMC Plant Biol. 20: 1-16. https:// doi.org/10.1186/s12870-020-02381-9

Shan, C. and Y. Wang. 2017. Exogenous salicylic acid-induced nitric oxide regulates leaf water condition though root osmoregulation of maize seedlings under drought stress. Braz. J. Bot., 40(2): 591-597. https://doi.org/10.1007/ s40415-016-0355-y

Sharafi, S., K. Ghassemi-Golezani, S. Mohammadi, 
S. Lak and B. Sorkhy. 2014. Evaluation of barleygenotypes (Hordeum vulgar L.) by droughttolerance indicesand multivariate analysis. Int. J. Biosci. 4(7): 117-129.

Sharma, N.K., S.K. Gupta, V. Dwivedi and D. Chattopadhyay, D. 2020. Lignin deposition in chickpea root xylem under drought. Plant Signal. Behav. 15(6): 1754621. https://doi.org $/ 10.1080 / 15592324.2020 .1754621$

Singh, S., A. Verma and V.K. Dubey. 2012. Effectivity of anti-oxidative enzymatic system on diminishing the oxidative stress induced by aluminium in chickpea (Cicer arietinum L.) seedlings. Braz. J. Plant Physiol. 24: 47-54. https://doi.org/10.1590/S167704202012000100007

Steel, R.G.D., J.H. Torrie and D.A. Dickey. 1997. Principles and procedures of statistics. A biometrical approach, $3^{\text {rd }}$ edition. McGraw Hill Book Co., Inc. New York, USA.

Subbarao, L.V., G.Pushpalatha, D. Subrahmanyam, K. Sreenu, T. Ram, B. Parmar and V. Rai. 2013. Effect of salt stress on seedling growth and antioxidant enzymes in two contrasting rice introgression lines. Ind. J. Plant Physiol. 18(4): 360-366. https://doi.org/10.1007/s40502-0140061-3

Sweet, S.K., D.W. Wolfe, A. DeGaetano and R. Benner. 2017. Anatomy of the 2016 drought in the Northeastern United States: Implications for agriculture and water resources in humid climates. Agric. For. Meteor. 247: 571-581. https://doi.org/10.1016/j. agrformet.2017.08.024

Tabassum, T., M. Farooq, R. Ahmad, A. Zohaib and A. Wahid, 2017. Seed priming and transgenerational drought memory improves tolerance against salt stress in bread wheat. Plant Physiol. Biochem., 118: 362-369. https:// doi.org/10.1016/j.plaphy.2017.07.007

Tian, L.Y., S.S. Yuan and S.M. Quiring. 2018. Evaluation of six indices for monitoring agricultural drought in the south-central United States. Agric. For. Meteorol., 249: 107-119. https://doi.org/10.1016/j. agrformet.2017.11.024

Toker, C., C. Lluch, N.A. Tejera, R. Serraj, and K.H.M. Siddique. 2007. Abiotic stresses. In: Yadav, S.S., Redden, R., Chen, W. and Sharma, B., editors. Chickpea breeding and management. Wallingford: CABI. pp. 474-496. https://doi. org/10.1079/9781845932138.023

Turkan, I., M. Bor, F. Ozdemir and H. Koca. 2005. Differential responses of lipid peroxidation and antioxidants in the leaves of drought-tolerant P. Acutifolius gray and drought-sensitive $P$. vulgaris L. subjected to polyethylene glycol mediated water stress. Plant Sci. 168: 223-231. https://doi.org/10.1016/j.plantsci.2004.07.032

Turner, N.C, G.C. Wright and K.H.M. Siddique. 2001. Adaptation of grain legumes (pulses) to water limited environments. Adv. Agron., 71: 193-123. https://doi.org/10.1016/S00652113(01)71015-2

Varshney, R.J, M. Thudi, S.N. Nayak, P.M. Gaur, J. Kashiwagi, L. Karishnamurhy, D. Jaganathan, K. Koppolu, A. Bohra, S. Tripathi, A. Rathore, A.K. Jukanti, V. Jayalakshmi, A. Vimula, S.J. Singh, M. Yasin, M.S. Sheshshayee and K.P. Viswanatha. 2014. Genetic dissectionof drought tolerancein chickpea (Cicer arietinum L.). Theor. Appl. Genet. 127: 445-462. https:// doi.org/10.1007/s00122-013-2230-6

Vicente-Serrano, S.M., S.M. QuiringPeñaGallardo, S. Yuan and F. Domínguez-Castro. 2020. A review of environmental droughts: Increased risk under global warming? Earth-Sci. Rev., 201: 102953. https://doi.org/10.1016/j. earscirev.2019.102953

Vidal-Macua, J.J., M. Ninyerola, A. Zabala, C. Domingo-Marimon, O. GonzalezGuerrero and X. Pons. 2018. Environmental and socioeconomic factors of abandonment of rainfed and irrigated crops in northeast Spain Appl. Geogr. 90: 155-174. https://doi. org/10.1016/j.apgeog.2017.12.005

Vural, H. and A. Karasu. 2007. Variability studies in chickpea varieties grown in Isparta, Turkey. Revista Científica UDO Agricola. pp. 35-40.

Walter, J., A. Jentsch, C. Beierkuhnlein and J. Kreyling, 2013. Ecological stress memory and cross stress tolerance in plants in the face of climate extremes. Environ. Exp. Bot., 94: 3-8. https://doi.org/10.1016/j. envexpbot.2012.02.009

Waqas, M., M.T. Azhar, I.A. Rana, A. Arif and R.M. Atif. 2019. Drought stress in chickpea: Physiological, breeding, and omics perspectives. In: Recent Approaches in Omics for Plant Resilience to Climate Change, Springer, Cham. pp. 189-227. https://doi.org/10.1007/978-3030-21687-0_9 
Wu, G., Z. Zhou, P. Chen, X. Tang, H. Shao and H. Wang. 2014. Comparative ecophysiological study of salt stress for wild and cultivated soybean species from the yellow river delta, China. Sci. World J., 10: 1-13. https://doi. org/10.1155/2014/651745

Zandalinas, S.I., R. Mittler, D. Balfagon, V. Arbona and A. Gomezcadenas. 2018. Plant adaptations to the combination of drought and high temperatures. Physiol. Plant. 7: 126-132.

Zandalinas, S. I., Balfagón, D., Arbona, V. and A. Gomez-Cadenas. 2017. Modulation of antioxidant defense system is associated with combined drought and heat stress tolerance in citrus. Front. Plant Sci. 8, 953. 